IdeAs

Idées d'Amériques

15 | 2020

Eau et gestion de l'eau dans les Amériques

\title{
Water crisis, policy making and the role of academia
}

An Interview with Pr. Kirsten Engel. Charles E. Ares Professor of Law, University of Arizona College of Law And Representative, Arizona House of Representatives, Legislative District 10.

\section{François-Michel Le Tourneau}

\section{(2) OpenEdition}

12 Journals

\section{Electronic version}

URL: http://journals.openedition.org/ideas/7716

DOI: 10.4000/ideas.7716

ISSN: 1950-5701

\section{Publisher}

Institut des Amériques

\section{Electronic reference}

François-Michel Le Tourneau, « Water crisis, policy making and the role of academia », IdeAs [Online], 15 | 2020, Online since 10 March 2020, connection on 25 March 2020. URL : http:// journals.openedition.org/ideas/7716 ; DOI : https://doi.org/10.4000/ideas.7716

This text was automatically generated on 25 March 2020.

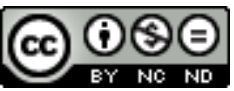

IdeAs - Idées d'Amériques est mis à disposition selon les termes de la licence Creative Commons Attribution - Pas d'Utilisation Commerciale - Pas de Modification 4.0 International. 


\title{
Water crisis, policy making and the role of academia
}

\author{
An Interview with Pr. Kirsten Engel. Charles E. Ares Professor of Law, \\ University of Arizona College of Law And Representative, Arizona House \\ of Representatives, Legislative District 10.
}

\section{François-Michel Le Tourneau}

FRANçoIS-MICHEL LE TOURNEAU (FMLT): Could you describe the situation of water in your state, Arizona?

Kirsten Engel (KE): This region is a desert, a very fragile desert and so the amount of water that's here is not sufficient to support a lot of the demands that we have for water. An enormous demand comes from agriculture but also from new housing development. We have a state which is a desert that has some native riparian surface waters, but at this point it is a very managed system where we are bringing in water from the Colorado River to supplement the use of groundwater. We are moving around water at a great expense and through a very complex matrix of laws and regulations, and through incentive programs to try to distribute both the water that is here naturally as well as water that we bring in from the Colorado river so as to supply the growth that you're seeing in this state.

FMLT: So what is at stake now is this repartition and distribution of all this water?

KE: Yes, I would say that. But we are also facing reductions in those sources of water. We're facing reductions in the amount of Colorado river water that will be available to Arizona. And so there have been changes to try to respond to those future reductions. We're also seeing reductions in groundwater, which is the other primary source of water in the state. Dropping water tables in many parts of the state are a result of groundwater pumping.

FMLT: What about the drivers of this water crisis?

KE: Broadly speaking they are agriculture, housing, and the increase in the population. But they are not equal. The agricultural sector uses by far the greatest amount of the water in the state of Arizona, around 70\%. It just dwarfs the use of water by anyone else. So even though you will hear from the agricultural sector that 
they try to conserve their water, it is a huge use of water and many of the crops that they are growing, such as alfalfa and cotton, use a lot of water.

FMLr: Does the contribution of this agricultural sector to Arizona's economy match this consumption of water?

KE: Well, there are different situations. For instance in the western part of the state you have Yuma. It is one of the most productive agricultural counties in the US, if not in the world, and there's no question that it is a big contributor to Arizona's economy. But they take their water directly from the Colorado river since they are located on it.

But there are other counties, such as Pinal county, which uses both groundwater as well as water they receive from the central Arizona project canal, an artificial structure that's bringing the water into the middle of the state. And in this case, while there have been studies showing that it is a large economic driver I think you do have to ask at what cost and if we can really sustain it into the future.

FMLr: This especially because, as you said, the perspective is of a dwindling water supply, meaning that Arizona will probably have to choose between population growth and the development of its agriculture...

KE: There has for a long time been the expectation that the footprint of the agricultural sector would shrink but that hasn't happened as rapidly as thought. And so we still have a large agricultural sector which does not want to yield water to others.

FMLr: The perspective of diminishing supply is due to climate change. Is there, here in Arizona, an awareness about that and is it consensual awareness or is it still a contentious question?

KE: On a political level, it is extremely contentious. I would say that the general public of Arizona realizes that climate change is happening because they are experiencing it, and that they think that something needs to be done. But politically, at least at the state level, that is still not something that is recognized publicly by all politicians. I have not found any real action addressing it or any real admission of it by the majority party here, which are the Republicans. So that has been a great frustration. The consequence is that we are not planning for the future when the scientists predict that our region will see more droughts and higher temperatures.

FMLT: And what you are seeing from your Republican colleagues, is it a flat denial or something like 'well, this is something we cannot do anything about'?

KE: We just do not talk about that...

FMLr: But you are a member of the Arizona State House Water Committee. How can they not talk about that on your Committee?

KE: They will just not use the term climate change or global warming or climate disruption or any of the other terms that you might have and they don't want to schedule or hear bills or propose legislation that would even plan for that. I have two bills in front of the legislature now. One is to have a statewide adaptation plan for climate change, and the second has both a plan for adaptation as well as a mitigation goal for the state of Arizona in greenhouse gas emissions. I have received no support on the Republican side nor do I have any indication that those bills will even be heard... This is where we are. 
FMLT: So they just don't talk about it?

KE: My sense is that they know what's happening, but politically they can't talk about it. They will be politically sidelined if they give voice to climate change. It's a larger political issue. It's the influence of the Trump politics which is reflected here. But I think if you were able to talk to many of them privately and there was no way that the conversation could become public, then they would show much more knowledge and preoccupation about climate change. Many of them are smart people, they know it's happening, they believe it's happening.

FMLT: This means that it is something that comes from Washington or from national politics? I mean that the possible cost of discussing climate change is more within the Republican party at a national level and within their constituencies? Or are they supported by some people here in Arizona who as well would not like them to talk about it?

KE: Well I don't know enough about the internal politics of the Republican party. But you have constituencies that are important in their party such as you know, hunters, anglers, recreational people, park people... All these resources are very much impacted by climate change and I think it is very clear to them that this is coming from climate change and something needs to be done. Those are maybe the pressure points and I just don't know how successful they're being right now.

FMLT: So local politics do play as well?

KE: Yes. Arizona is very much split these days. The Democratic party is increasing mostly because of demographics. So there could be right now even more of a hunkering down from the Republicans. You might think that the closeness of the two parties would make them more open-minded politically, but it's actually having the opposite effect.

FMLT: You have a very unusual profile because you're a faculty here at the University of Arizona at the same time you are a state representative. Do you think that things complement one another or do you have to be schizophrenic?

KE: There's been a feedback effect on both sides that I benefit from as a faculty here. I have resources at my disposal, I have people I can talk to and this has been invaluable in getting up to speed on water issues in the state or understanding climate change or defining what are the policies that we could adopt and what their impacts would be. There are people at the University that I can go to ask questions or whom I can ask to come to the legislature to testify on bills - if we can get the bills heard! Then on the other side, I am working to educate people, students and faculty about how the legislature works. A lot of the scientific research available is not necessarily impacting policy. So we can have the best research on climate change and yet unless we figure out how to make this accessible by policymakers and make it really fit into a political narrative, it will not actually be used to forward climate policy.

FMLT: What I understand then is that there should be a dialogue between scientists and politicians and this dialogue doesn't take place. Do you think that it is we as scientists who should do whatever it takes to make this dialogue happen? Or should policy makers look more our way?

KE: I really think the latter really should be the most important thing. Policy makers should say 'okay, we have a policy issue here, we know that we have drought that is affecting our state and our population in so many ways, let's go to the experts that we find in our universities and ask them why are we seeing this, how long has this been going on, how long is it going to last, what can we do about it, what is it going to 
cost?' It really seems that would be the first thing but since that does not seem to be happening sufficiently, the scientists need to go to the policy makers.

FMLT: What is the vision of the policy makers about the academic world in general?

KE: There is this vision from the political elites of the Republican party that the universities are full of well-paid liberals pushing their own agenda. So it is not the place where they will go for solutions.

FMLT: So is it an impossible dialogue?

KE: Well, there are intermediaries. Part of the answer is finding the spaces in between, out of the political limelight, where there can be dialogues and exchanges of information.

FMLT: And where is the intermediate space?

KE: NGOs, advocacy groups, foundations, groups like the Sonoran Institute here. There is not as much in Arizona but we could learn from what happens in other states.

FMLT: And shouldn't universities try to inform policy makers the same way they develop their outreach activities towards high schools or the general public?

KE: Yes. There have been efforts around 'science translation', but it's more about how we talk about science and not about creating dialogue to address policy priorities. We could take example of the departments of Public Health because what they do is exactly at this interface between science and its application in policy.

FMLT: What is exactly your role in the State Assembly here in Arizona?

KE: I'm an elected representative from a district. There are 30 districts in the State and each has two representatives and I am one of those, so I'm one of 60 members in the House. I do serve in the House committee that deals with water and environmental issues, which name is House committee on natural resources energy and water. I was the senior member before, but I am no longer. However I've been on that committee since I was elected so this is my fourth year on that committee. As a result of that, I'm often pulled into other areas. These might be more informal committees that my status as a representative gives me an invitation to join. For instance last summer there was this drought contingency plan stakeholder meetings for the Colorado River and although I was not an official member of the committee I was able to participate fully in that and, even taking part in votes and giving my opinion on the drought management issues. So that the amount of influence of my current position is not strictly limited to the House.

FMLT: Arizona is located at the border with Mexico and it shares water with this other country, for instance from the Colorado River...

KE: It is a very large issue policy wise but I think the surprising thing is that it does not get very much attention here. The United States and Mexico recently signed an agreement known as "Minute 323" according to which the U.S. and state water agencies will invest millions of dollars in water conservation projects in Mexico and, in return, be entitled to a portion of the water conserved. Also under the agreement, Mexico will continue to store water in Lake Mead and will share in any shortages declared on the Colorado River.

FMLT: This way of framing the situation is very interesting because it reflects the general orientation about water in the US. In general, when people refer to water they mean the use 
of water for human use. But the ecosystem uses water as well and what is not 'used' by Mexico could serve to maintain the ecological function of the delta of the Colorado, isn't it?

KE: Yes, unfortunately the western approach to water law is all grounded on the 'use it or lose it' doctrine. If a senior appropriator of water rights does not use its allocation, then more junior users can claim this water and take it. It is an issue I have been very aware of and I am proposing a bill in this session which would consider that keeping the water in the ecosystem is a legitimate use of water and that it should count as much as irrigating fields. This would make it clear that a beneficial use of the water is just to leave the water in the ecosystem.

FMLT: And then it provides in turn ecological services that are beneficial for the population.

KE: That's exactly right. But there's been inattention to that. Arizona has a very cumbersome process of trying to reserve water that will then not go to an economic use but will be otherwise reserved in the ecosystem. That was the genesis of my bill, which tries to make it easier for that water to be left.

FMLT: Do you have any perspective on this issue of water worldwide? Do you think that there is a worldwide crisis of water?

KE: It is certainly my understanding that this is happening all over the world and in so many other places in the United States. There was a drought in Georgia not very long ago, California had enormous droughts... But this is also a source for new cooperation. Arizona does have a relationship with Israel about water management and we are trying to foster other ones. There is a lot of interest by policymakers here in desalination techniques as a way of augmenting our water resources. My own view of that is that it is incredibly expensive and not necessarily feasible economically or maybe even politically or as a matter of engineering. And yet it seems that members of the Republican Party will focus a lot on that and try to bring in experts from other countries on desalinization. What I see is that we should be spending more time looking at water conservation or how we are using our water, what crops we are growing and if they are the right crops for a desert environment, rather than looking at just augmenting our water resources through desalinization.

FMLT: And what about all the policies that were developed in the Southwest of the US to make water a commodity and install a more rational use of it by raising its price?

KE: Arizona is a place where we could do that more and the sad thing is, and it may be surprising, that we really don't. Water is just very cheap in Arizona and too cheap, so that we are overusing it, we are not actually properly pricing it today. It's just a little bit too easy to go through the political process to get your water, so actually while there is some marketing of water, it is much less than you might expect. Something that might be actually an improvement in Arizona is to have more of that. But now there are also fairly controversial proposals about trying to transfer water from one watershed to another or from one aquifer to another area. That might be something that would be okay under a market system, as long as you pay for it, but I think there would be some political resistance to that.

FMLT: So we are back to the debate of increasing water supply vs better managing the water that is available?

$\mathrm{KE}$ : Yes and one thing to that is interesting to note is that groundwater pumping is regulated in the more populated areas of Arizona. There's a cost to groundwater in those areas because people pay to store groundwater. They don't use the groundwater that they have access to and purchase Colorado River water instead. So 
there is something of a price on water here in the regulated areas, but outside of the regulated areas there's just this notion known as 'reasonable use' so if you were landowner you can pump as much as 'reasonable' which is basically unlimited use on your land. We've had entities coming in from outside Arizona and growing crops that they then ship back to their home countries such as in the Middle East because it's just so cheap to use our water because we're not putting a price on it, essentially it's just basically the price of the land.

\section{AUTHOR}

\section{FRANÇOIS-MICHEL LE TOURNEAU}

François-Michel Le Tourneau est directeur de recherche au CNRS et directeur-adhoint de l'UMI iGLOBES (CNRS-ENS-Université d'Arizona). 